\title{
THE RESULTS OF A PRELIMIMARY ARCHAEOLOGICAL SURVEY OF MORETON ISLAND
}

\author{
RICHARD ROBINS \\ Mustralian Eavironneatal Sciences \\ Griffith University
}

A preliminary survey of the Moreton Island was undertaken as part of a larger research framework designed to examine the feasibility of using problem-oriented research projects as a basis for the assessment of significance of the archaeological resource in the Queensland context and to suggest ways in which such research might be conducted within the present structure of Queensland Public Archaeology. Moreton Island was chosen as a staging ground for this research for the following reasons.

1. Two previous archaeological surveys had been undertaken on the island, the first in 1964 [by V.V. Ponosov of the Psychology Department, University of Queensland, as part of a general Moreton Bay survey], the second in 1975 [by M. Morwood as a site recording project for the Archaeology Branch, Queensland Department of Aboriginal and Islanders' Advancement]. Both offered data with which the results of the present survey could be compared and assessed.

2. As sand mining on the Island appeared imminent, it was considered important to add to the knowledge of the Island's prehistory should the archaeological record be threatened or destroyed.

3. Moreton Island is the only sand island in southeast Queensland which has not suffered massive disturbance through sand mining or urban or other economic developments. Thus, the archaeological record was considered to be similarly undisturbed and in a relatively "pristine" environmental context.

4. As an island it could be treated as a well defined and circumscribed sampling universe.

5. Good geographical data was available in the form of $1: 25,000$ topographic maps, recent low level aerial photography and an Environmental Impact Study (Heath and Partners 1976) which included comprehensive environmental data.

6. It fell within the scope and aims of the Moreton Region Archaeological Project (M.R.A.P.) initiated by Dr J. Hall, Department of Anthropology and Sociology, University of Queensland (see Hall 1980). The results could be incorporated into that project and thus contribute additional information towards a regional prehistory. 
The survey was designed to address four questions as follows:

1. Is there a pattern of site location and distribution on Moreton Island?

2. Why are sites located where they are?

3. What is the archaeological "significance" of Moreton Island?

4. Is there an alternative and more useful/productive procedure for assessing the scientific significance of Archaeological sites than that currently used in public archaeology in Queensland?

This paper will address the first question only and will present only those data which, relate to the survey.

A simple random sampling procedure was chosen because it involves few assumptions about the population to be examined (Redman 1974: 10). Therefore it could provide contrast in survey design with the two previous archaeological surveys of the Island, both of which had been judgemental (Robins 1983). Furthermore, there was a need to obtain as much information as possible before sandmining commenced on the Island. Whereas earlier surveys had concentrated on the Island's coasts with an emphasis on recording as many sites as possible, this project aimed at examining areas for patterns of archaeological evidence. Thus, comparisons between the different survey strategies could be made while maximising the coverage of the Island in the time available. Finally, it was reasoned that, even if no sites were found, the employment of ' a probability sample would permit more reliable statements about the Island's archaeological record and, consequently, better informed general recommendations concerning future management and development of that record.

In order to provide an additional control for comparison of results, I attempted to make the survey's duration equivalent to the D.A.I.A. survey of 1975 (28 days or approximately 448 person hours). The survey was commenced in May, 1979. The sampling universe included al1 of Moretion Island as presented on the 1:25,000 topographic map series (based on. aerial photographs taken in 1967), but excluded areas that had either prograded or eroded since 1967. Quadrats of $1 \mathrm{~km}^{2}$ were chosen as survey units. The sampling frame consisted of all $1 \mathrm{~km}^{2}$ units on the map's grid that had more than $600 \mathrm{~m}^{2}$. of land surface; quadrats with less were omitted.

The sampling frame comprised 222 quadrats. Based on an estimation of the number of quadrats or parts thereof that could be covered in 28 days, 45 quadrats, or approximately $19 \%$ of the Island's area, were selected from a random number table (Figure 1) (Zehna 1974: 398). The sample included.25 full quadrats and 20 with some portion in the ocean. of the latter, 11 comprised less than 50\% land and 61 less than $25 \% 1$ land. Quadrats were located using aerial photographs and compass bearings. The rugged terrain and dense vegetation prevented precise definition of the grid within the limits of the time and nature of the exercise. This imprecision should be regarded as a potential but minor source of error. The sampling intensity was variable. Where possible, traverses were made across quadrats at $10 \mathrm{~m}$ intervals; however, dense vegetation in some areas made this an impossible standard to maintain. In 10 cases, only partial, examination could be made. The range of 


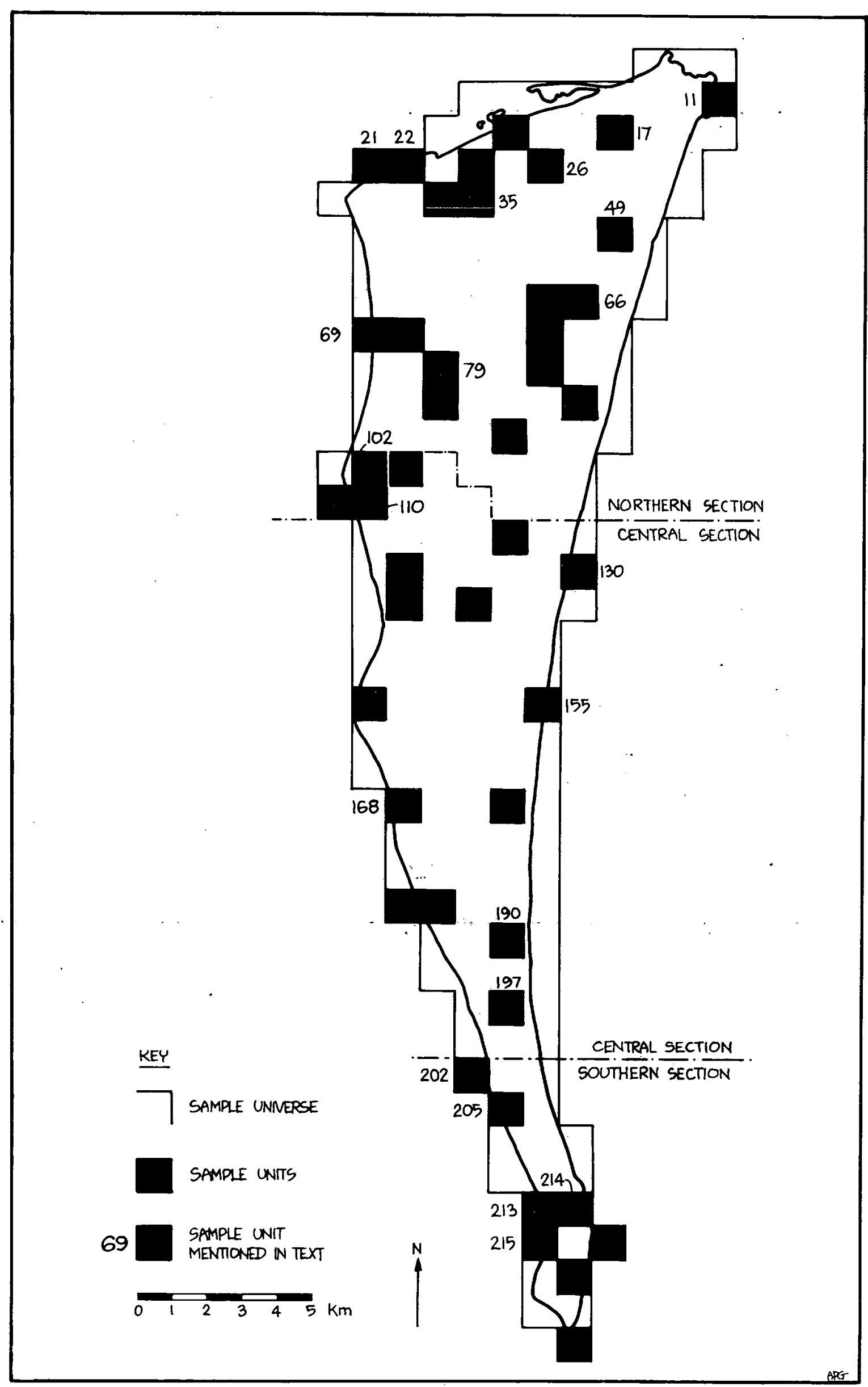

Figure 1. Moreton Island map showing surveyed quadrats. 
quadrat size and differences in survey conditions resulted in a variable ratio of person-hours spent per quadrat (Range $=1-30$ person-hours; Mean $=9.7$ person-hours) - This survey cannot be regarded as a "true" probability survey because coverage of some quadrats was only partial. Nevertheless, because the sample was relatively large to begin with, error is considered minimal.

\section{FIELD METHODS}

The field methods of site recording were designed to approximate those often used in public archaeology in Queensland, both in Environmental Impact Studies and the Cultural Resource Management Programme (Robins 1983). They also approximated the methods used by Ponosov and the D.A.I.A. which involved site location on topographic maps or aerial photographs, descriptions of general characteristics (e.g., size, depth of deposit, stratification and components) and unstructured surface collections. The D.A.I.A. survey placed sites within a general environmental context and provided a photographic record.

For the purposes of this survey a site was defined as a discrete area with evidence of past Aboriginal activity. A distance of $10 \mathrm{~m}$ or more from the edge of one site to the edge of another was considered a measure of discreteness. Recording of sites included the following information categories.

Location: Sites were located on aerial photographs taken from an a1titude of 12,000 feet in 1972, and on the 1:25,000 R834 Edition 1 topographic map series for the Island.

Size: Size was noted to the nearest $10 \mathrm{~cm}$ for horizontal measurement and the nearest $1 \mathrm{~cm}$ for vertical measurement.

Density: The maximum surface density of surface material was noted according to the following scale: $I=1-4$ items $/ \mathrm{m}^{2}$; II $=5-10$ items $/ \mathrm{m}^{2}$; III $=11-20$ items $/ \mathrm{m}^{2} ;$ IV $=21$ items $/ \mathrm{m}^{2}$. :

Stratification: Stratification was noted only where this could be done without excavation.

Condition: The type and degree of site disturbance and the presence of weathering of site components was noted.

Environment: The site was placed within a land unit (Coaldrake and Turner 1976) and vegetation (Durrington 1977) category and its general situation was described.

Components: The presence of stone artefacts and manuports, faunal and floral remains and charcoal were noted. Faunal samples were collected for identification.

Collections: Unstructured total collections were made on selected sites from which neither Ponosov nor Morwood had previously made collections. 
Sites were photographed using black and white and colour films. In some cases, sketch plans were made. The time taken to survey each quadrat was also noted.

\section{SURVEY RESULTS}

The survey yielded 93 sites. All were either types of shell middens, stone artefact scatters, or "point sites" comprising single artefacts or manuports. No Bora rings, stone arrangements, art sites, carved or scarred trees, stone fish traps, occupation deposits in rock shelters or burials were found although these types of sites have been recorded on other local sand islands and for the coastal and subcoastal areas of southeast Queensland (Quinnell 1975: 171). There is a reference to a Bora Ring near the Yellow Patch (Byrne: 1912) and Ponosov (N.D.: 77) recorded a burial at the eastern end of the Tangalooma track, near Eagers Swamp. Disturbance of some form was a significant factor in the identification and recording process. of the 93 sites recorded $95 \%$ exhibited some form of post-depositional disturbance. Pigs (39\%), European development $(14 \%)$ and natural erosion $(11 \%)$ were the three main causes.

\section{THE SITES}

Sites were classified into three general types as follows:

(1) in situ, deflated or scattered middens variously comprised of marine shells, and other faunal remains, stone artefacts, manuports and charcoal, and sand;

(2) stone artefact scatters comprised solely of stone artefacts, manuports and stone fragments,

(3) point sites comprising of single artefacts or manuports.

An assumption was made that unworked stone, the presence of which could be discounted as the obvious result of European or other animal behaviour, and which was further than $100 \mathrm{~m}$ from a stone source, was the result, of Aboriginal activity. The combination of limited stone sources and a relatively. undisturbed sand island is unique to southeast Queensland and this data could enhance knowledge of the spectrum of site types and the selection and distribution of stone.

Middens comprised the most common type of site ( $79 \%$ with shell only and $4 \%$ with both shell and stone material). By far the most extensive midden was Site 1 , The Cape Site. It consisted primarily of 90,000 square metres of eroded and deflated midden on top of Cape cliff above the northern end of the eastern beach. Shell species included Thias orbita, Turbo petholiates and Crassostrea commerclalis from the rocky headland below, and Donax deltoides from the nearby surf beach. Stone artefacts included cores, core tools, flakes and retouched flakes; but most stone material consisted of sandstone and volcanic fragments. On the crest of a ridge running through the site are several residuals which contained, in profile, thin, variable and discontinuous layers of shell and stone material at depths of up to $1.5 \mathrm{~m}$. 
The majority (55\%) of sites recorded in the north of the island comprised small, low density shell scatters ranging in size from $25 \mathrm{~m}^{2}$ to $\mathrm{Im}^{2}$. Donax deltoides (pipi) was the dominant shell species, occurring in $83 \%$ of the sites. On the northwestern coast between Comboyuro Swamp and the western shoreline a gradation in the shell species represented in sites was noted from Donax deltoides in the north, to Anadara trapezia plus Donax deltoides in the centre, to Anadara trapezia in the south.

Most middens in the north were out of their primary depositional context. Exceptions include a small mound of Anadara trapezia at the southwestern end of Comboyuro Swamp (site 41), one smal1 compact pile of Donax deltoides in Quadrat 66 (site 19) and six small compact piles of Donax deltoides and one of Anadara trapezia (sites 31-37) at the edge of an unnamed lake in Quadrat 79. (Figure 2).

A single scattered midden on the central western coast (site 54) was similar in size to those further to the north, although it contained only estuarine species (Anadara trapezia, Crassostrea commercialis and Polinices sp.).

In Quadrat 130, on the central east coast, 6 middens (sites 44-49) were located in foredune situations (Figure 3). Their character differed from those found in the northern quadrats. Two (sites 44 and 48) occurred as thin layers of Donax deltoides associated with a dark layer of sand and charcoal in the face of an eroding dune. Consistency in size range, shell orientation, lack of shell fragmentation and the association of charcoal with the deposits, suggested these were in situ primary deposits. Four dense and extensive shell scatters, ranging in size from $25 \mathrm{~m}^{2}$ to $120 \mathrm{~m}^{2}$, were recorded in depressions between sandhills in the vicinity of the shell deposits. All contained Donax deltoides and two contained large numbers of stone artefacts including flakes, retouched flakes and cores from volcanic stone and ferrocrete.

In the southern part of the island the character of shell middens again changed. Between the southern side of the Big Sandhills and Reeders Point, 34 middens were recorded, most near the west coast (Figure 4). They varied in area from $1 \mathrm{~m}^{2}$ to $5,000 \mathrm{~m}^{2}$ with a mean of $424 \mathrm{~m}^{2}$; however, $59 \%$ had an area of $10 \mathrm{~m}^{2}$ or less. Only $18 \%$ of all middens exhibited any indication of deposit depth or were undisturbed deposits. One (Site 59), comprised nine small piles of shell associated with' a stone artefact scatter. in area of bare sand. Site density. ratings $I$ and II predominanted (Figure 4).

The shells represented in scatters contained species both from the eastern surf beach (Donax deltoides) and the southwest estuarine coast (Anadara trapezia, Pyrazus ebininus, Crossastrea commercialis, Polinces sp.). Donax deltoides is represented in $50 \%$ of the middens. The number of species represented in the middens varied between one and five:

Seven artefact scatters were recorded, five on the east central coast and two in the centre of the island towards the southern end. These constitute $8 \%$ of all sites recorded. Site area was highly variable, ranging from $42 \mathrm{~m}^{2}$ to $280,000 \mathrm{~m}^{2}$. All were sparse scatters with a density rating of $I$. All contained pebbles of quartzite or volcanic origin. Fragments of volcanic material and flakes were found in five of the sites, cores in four, retouched flakes in three and a core.tool in one. Collections were made on four of these sites.

Nine $(10 \%)$ point sites were located, seven in the north around Lake Jabiru and Comboyuro Swamp, one in the Little Sandhills and one on the southwest coast. Five consisted of fragments of sandstone, two 

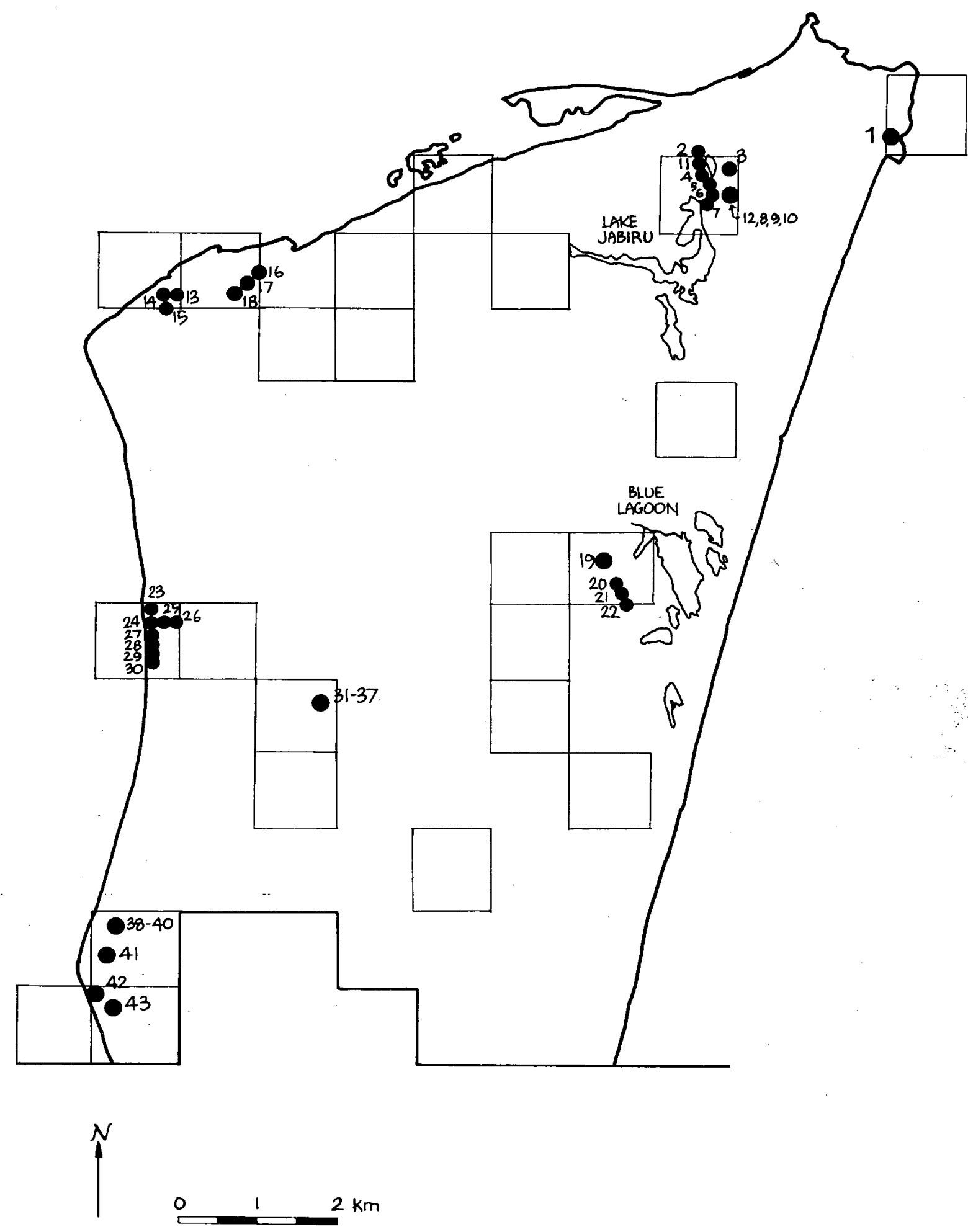

SITE

Figure 2. Northern Section of Moreton Island showing quadrats surveyed and sites found. 


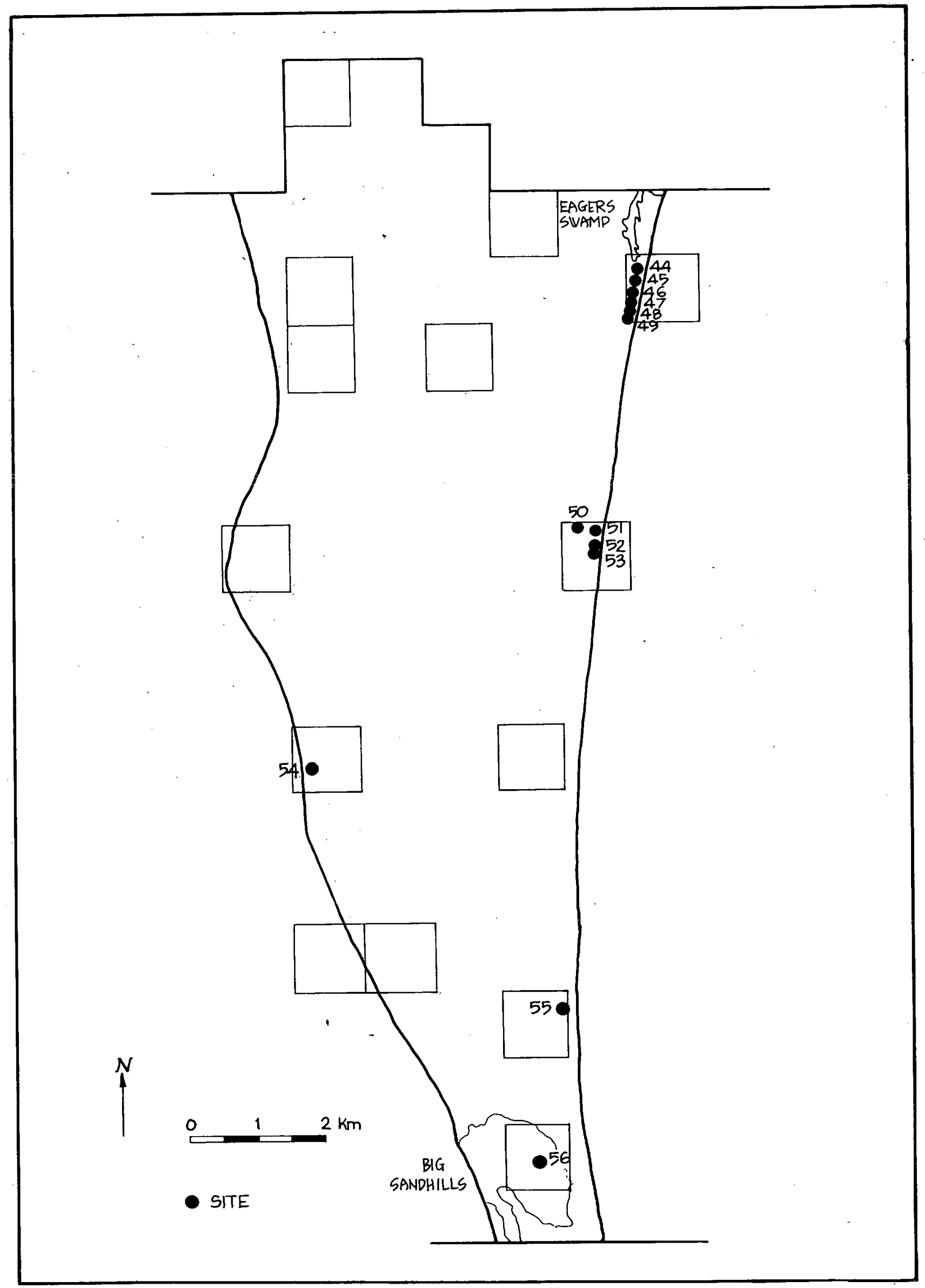

Figure 3. Central Section of Moreton Island showing quadrats surveyed and sites found. 


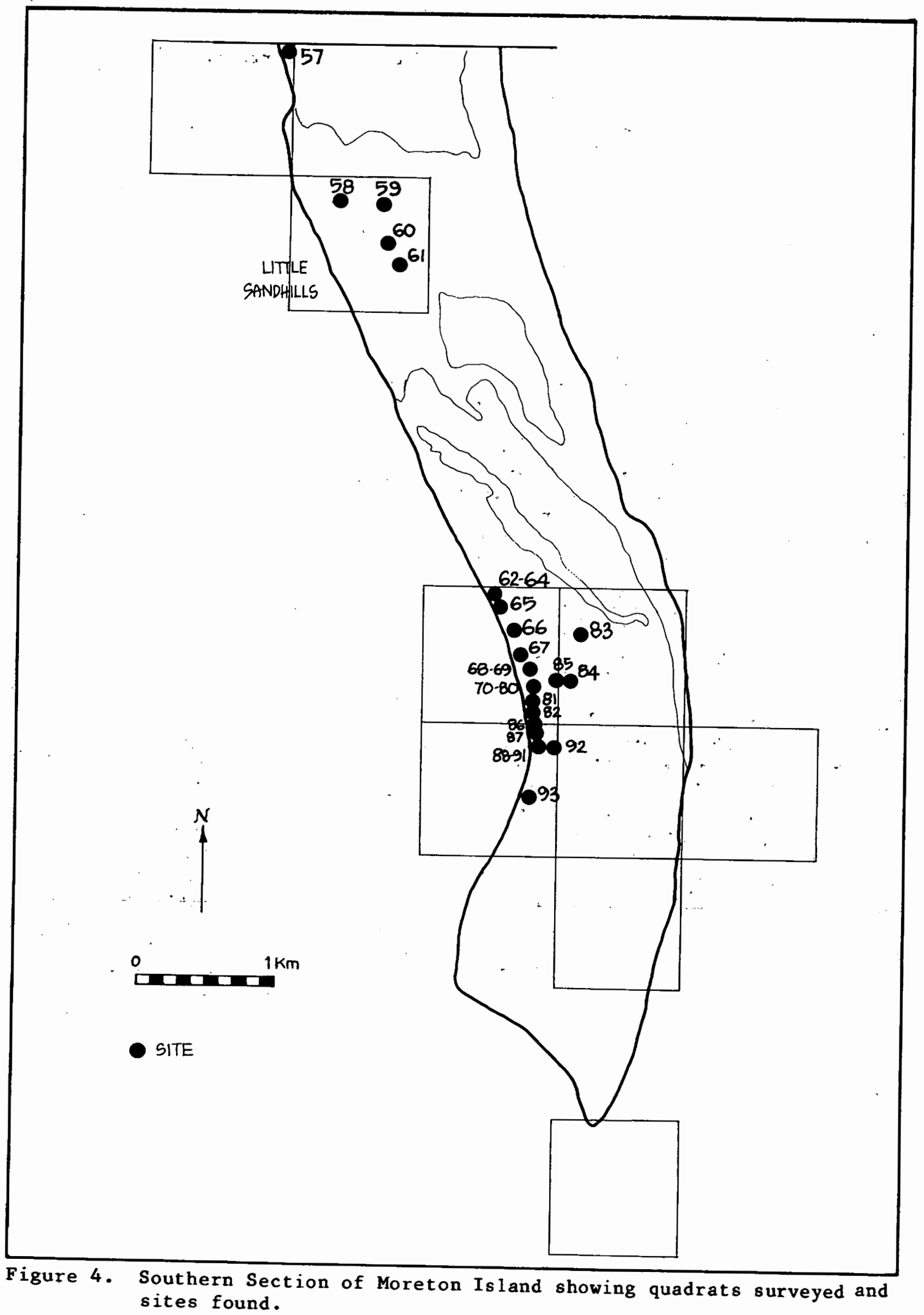


comprised fragments of volcanic material, one was a quartzite pebble and one a chalcedony flake.

\section{SITE LOCATION AND DISTRIBUTION}

Sites were found in nine of the 22 vegetation units identified by Durrington (1977). Seventy-one percent of all sites were situated in open or closed forest dominated by Tristania conferta and the open forests and woodlands of the northern and southern sections. Sites were found in only 11 of the 29 land management units described by Coaldrake and Turner (1975) (Figure 6). Of these, 68\% occur in low flat to depressional sandplains (Unit 9), strandlines and swales (Unit 23) and broad depressional areas with many lakes and swamps (Unit 22).

The archaeological site distribution pattern corresponds roughly to Durrington's (1977: 4) tripartite vegetation division of the island. In the north, sites clustered around lake or swamp systems (within approximately $200 \mathrm{~m}$ ) on flat land often on the crest of a ridge or. dune in open woodland or forest. In cases where lakes or swamps were fringed by a variety of vegetation types (e.g. Lake Jabiru), sites were only found in open forests or woodlands. Not all swamps were associated with sites. For example, no sites were found around swamps in Quadrats 25 and 35. However, in these cases other factors such as flat land or open forests or woodlands were absent. In only one case (Quadrat 49) was a site not found in a locality which met all locational criteria.

The important exception to this pattern in the northern section is Site 1, an extensive site situated on the top of Cape Cliff in what was originally closed grassland." It overlooks a surf beach and rocky shoreline and is directly adjacent" to the only source of stone on the island. (see Richardson 1979).

In the central section the pattern of site location changes (Figure 3). Only one site, a small scatter of shell (Site 54) was found on the west coast located between the southern end of Comboyuro Swamp and the Big Sandhills. No sites were discovered in the central section of the island, except in the southern Big Sandhills where an extensive artefact scatter (Site 56) was found. The remainder of central section sites were located on the east coast within $400 \mathrm{~m}$ of the sea. All were in foredunes or blowouts which had undergone some morphological change since site deposition. Sites 44 to 49 were located on foredunes in Spinifex hirsutus open grassland within $500 \mathrm{~m}$ of Eagers Swamp. Sites 50 to 54 were in blowouts in the eastern wind-shear slopes at elevations between $30 \mathrm{~m}$ and $50 \mathrm{~m}$ a.s.1. These, all stone artefact scatters, were found in bare and eroding sand and their original depositional context could not be ascertained. They could have been originally situated in closed scrub, open woodland or bare sand. The nearest current permanent water source to these sites, Eagers Swamp, is approximately $4.5 \mathrm{~km} \cdot$ to the north, although a semi-permanent lake lies $1.7 \mathrm{~km}$ to the south. Springs and soaks occur along the beach at regular intervals subsequent to periods of high rainfall: Site 55, a stone artefact scatter, was located on sand rock and bare sand in the centre of a circular blowout in closed heath.

Southern section sites were concentrated on the west coast, although some occurred in bare sand dunes in the centre of the island. (Figure 4). No sites were found on the east coast, albeit $650 \mathrm{~m}$ was the maximum distance inland recorded for any one site. With the exception 
of sites in the Little Sandhills (Sites 58-61), all were located on flat terrain or on an adjacent ridge slope, in open forest or woodland within $300 \mathrm{~m}$ of a swamp. However, only three were within $100 \mathrm{~m}$ of a swamp. No sites were found on the crests or slopes of hills and only seven sites were located within $30 \mathrm{~m}$ of the present coastline. Sites in Quadrat 205 were at the base or sides of depressions which contained semi-permanent water. Although these were situated in bare sand dunes there were indications in the form of dead trees (Callitris columellaris and Eucalyptus intermedia) that this area had once been open forest.

\section{SUMMARY}

A simple random survey comprising $451 \mathrm{~km}^{2}$ quadrats yielded 93 sites. No substantial in situ deposits were recorded during the survey. The majority of sites were small scattered or disturbed middens or stone artefact scatters. No sites were recorded on or within $200 \mathrm{~m}$ of the north coast or the southeast coast and only one site was recorded in the central section. The maximum distance any site on Moreton Island can be from a coastal boundary was approximately $3.8 \mathrm{~km}$. Although approximately half of the sites were less than $250 \mathrm{~m}$ from the present shoreline, one quarter of them occur more than $500 \mathrm{~m}$ from the shore.

Table I: Site distance from the nearest shoreline.

\begin{tabular}{crrr} 
Distance from Present Shoreline & Number of Sites & Percentage \\
\cline { 1 - 2 }$<250 \mathrm{~m}$ & 51 & 54.7 \\
$250-500 \mathrm{~m}$ & 17 & 18.3 \\
$500 \mathrm{~m}-1.0 \mathrm{~km}$ & 5 & 5.4 \\
$1.0 \mathrm{~km}-1.5 \mathrm{~km}$ & 18 & 19.4 \\
$1.5 \mathrm{~km}-2.0 \mathrm{~km}$ & 2 & 2.2 \\
& 93 & 100.0
\end{tabular}

A clearer pattern emerges when site distribution patterns are related to the island's three major physiographic areas. The average distance of sites from a coastline in the northern section was $800 \mathrm{~m}$, in the central section $200 \mathrm{~m}$ and in the southern section $100 \mathrm{~m}$. In the northern section a high percentage of sites were more than $500 \mathrm{~m}$ from a coast. In the central section most sites were within $250 \mathrm{~m}$ of, but none more than $500 \mathrm{~m}$, from a coast. In the southern section the majority were less than $250 \mathrm{~m}$ from a coast with a small percentage between $500 \mathrm{~m}$ and $750 \mathrm{~m}$ (Figure 5).

In the northern and southern sections most sites were located in open woodland or forest, on flat terrain near a swamp. In the south, sites were concentrated on the west coast, but in the north they were more widely distributed. In the central section sites were concentrated on the east coast. In the north of this section they were situated near a swamp; however, in the south all were in bare sand and deflating areas and were probably out of their primary depositional contexts. 

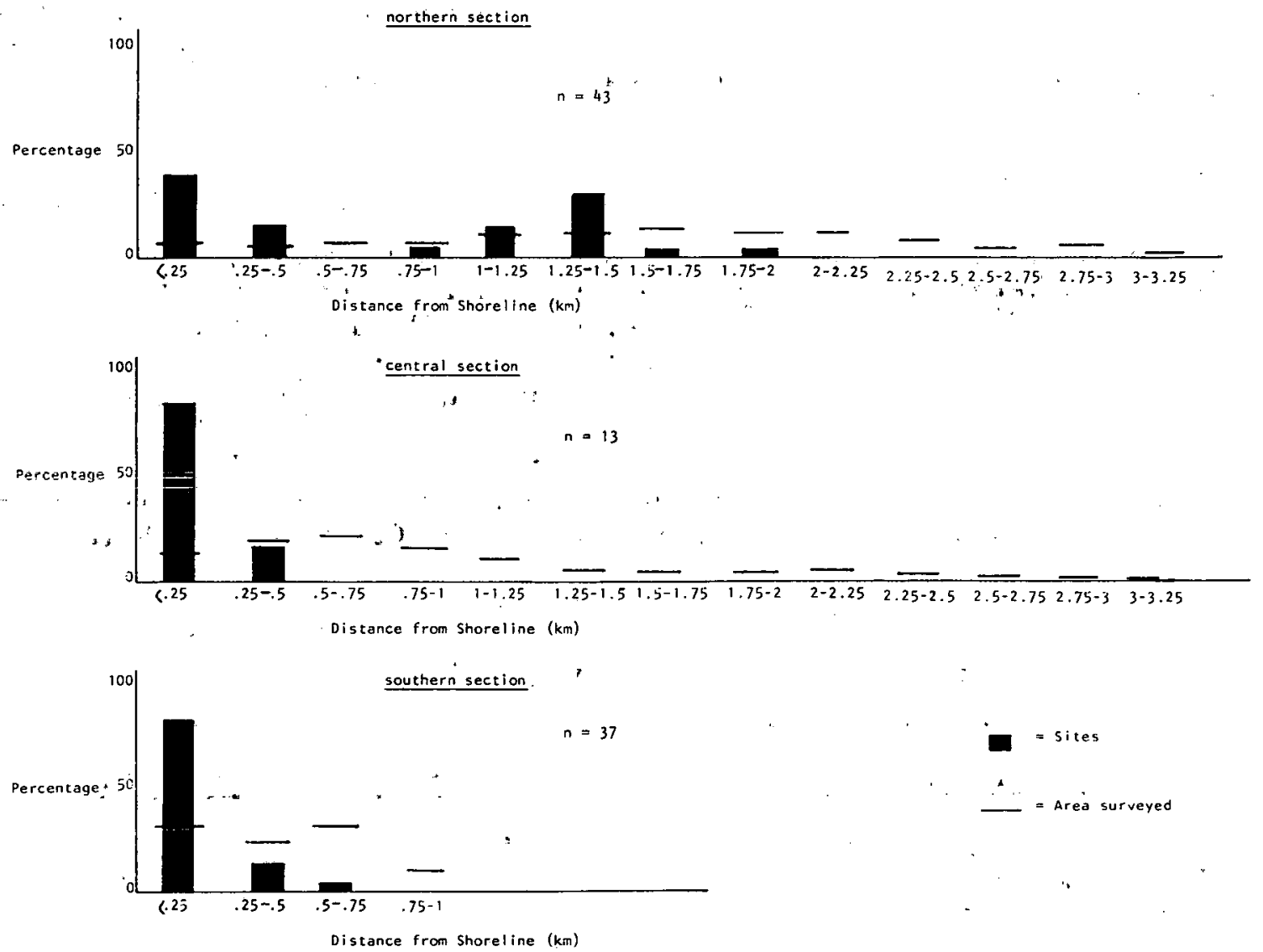

Figure-5. Comparison of expected and-actual distances of sites to the nearest coast for three major island sections

\section{DISCUSSION}

Before interpretation of this pattern can be undertaken, the possibility of sample bias must be considered, particularly with respect to relationships between sites and their distance to coasts, vegetation units and land management units.

In discussing the relationship between site distribution and coastine proximity, the three physiographic divisions of the island will be used. In the northern section the sample was evenly distributed up to $2.75 \mathrm{~km}$ inland, with the sample size varying from between $5 \%$ and 13\%. Despite this, there is little correlation between the sample size and the number of site recorded (Figure 5). The site distribution 
pattern clearly reflects the concentration of sites on the coast and around lakes further inland. It stands in marked contrast to the distribution of sites in the central section. Although $80 \%$ of the sample for this section was less than $1.25 \mathrm{~km}$ from the coast, the $0.5-0.75 \mathrm{~km}$ zone with the largest sample (22\%) had no sites, while the $0-0.25 \mathrm{~km}$ zone, with a $12 \%$ sample contained $76 \%$ of the sites. The decline in sample size is also a reflection of the decline in the sample area further inland. In the southern section the zones surveyed up to $0.75 \mathrm{~km}$ inland were similar in sample size $(32 \%, 26 \%, 32 \%)$. Although the $0-0.25 \mathrm{~km}$ zone was of an equivalent size to the $0.5-0.75 \mathrm{~km}$ zone, far more sites were recorded in the former. The $0.75-1 \mathrm{~km}$ zone represented $10 \%$ of the surveyed area, but no sites were recorded there. Even if sites do exist at this distance inland, they are unlikely to be sufficiently concentrated to alter the general pattern. Thus the pattern of site distribution is not a reflection of sample bias. That is, there is not a consistent relationship between the area surveyed and the number of sites recorded.

The patterns produced by the survey, with respect to the vegetation units, may also reflect sample bias. Four vegetation units not surveyed included lakes and swamps (Units 10 and 11) where surveying was not feasible, and two others (Units 8 and 9) on the Cape Moreton headland which were not included in the sample. Clear patterns of site location can be recognised. Although large, Units 14 and 19 are under-represented, with. low site densities of 0.4 and 2.0 sites $/ \mathrm{km}^{2}$ respectively. Units $2,4,5,7,12,20$ and particularly Unit 22 (which has a restricted area in the southern section) are over-represented (Figure 6). The density of sites in these units ranges from between 3.4 and 23.3 sites $/ \mathrm{km}^{2}$. Thus, in this instance there is no clear correlation between the size of the vegetation unit sampled and the number of archaeological sites. However, the relationship between sites and vegetation units was not always clear cut. For example, although $24 \%$ of sites were in open forest and woodland (Unit 19), only one site was found on the west central coast which is vegetated primarily with open forest and woodland. Thus, while vegetation type may be an important factor in determining site location, it is not the only factor to be considered.

- of the 29 land management units identified for Moreton Island, two were not sampled. Unit 17 consisted of lakes and swamps and Unit 29, a small area of ridges and escarpments on Cape Moreton, was not represented. There is no consistent relationship between site abundance and area of unit surveyed (Figure 7). Units 4,6, 9, 18, 22, 23 and 28 were over-represented while Units 3,10 and 11 were under-represented. Site density yaried considerably (between 1.3 and 142.9 sites $/ \mathrm{km}^{2}$ ), although it is likely that the larger figure may be biased due to the small sample. However, the distribution of sites is not purely a function of a direct correlation with land management units. It appears likely that the pattern of site location is related to specific factors within each land unit. For example, it is possible to predict on the basis of this survey that sites will be found in only three of the nine vegetation units that occur within land management Unit 22 . Thus the use of these particular land management units may need to be refined before they may be of predictive use in future archaeological surveys. 


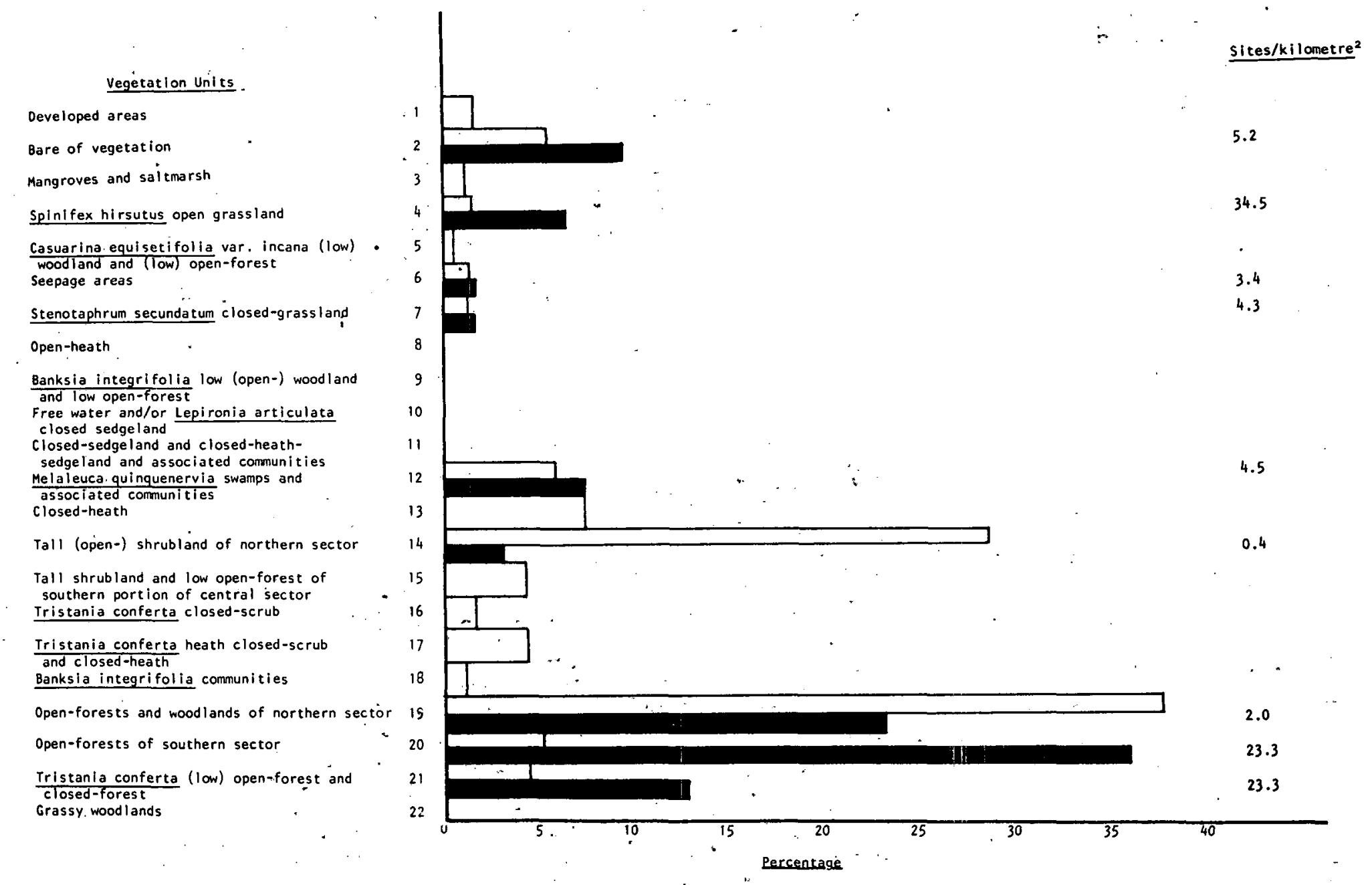

Figure 6. Percentage of sites and sites $/ \mathrm{km}^{2}$ compared to Vegetation Units surveyed. 
Land Management Units

Elevated, undulating sandhill surface

Isolated peaks and ridges

Eastern wind shear slopes

Active giant sand dunes

Western escarpment

"Blow out" sand dunes and slopes

Foredunes, berms and beaches

Low gently undulating sandplain

Low flat to depressional sandplain

Giant sandhills and ridges

High elongate sand ridges

Rolling sandhills

Lower linear transgressive dunes

"Blow out" sand dunes

Western escarpment

Valleys and depressions

Lakes and swamps

Foredunes berms and beaches

Higher sandhills; ridges and valleys

Low sandhills and slopes

Broken swampland

Broad depressions; many swamps and lakes

Strandlines and swales

Low disorganised sandhills

Foredunes and beach

Sandbars; of fshore and spit islands

Backswamps

Rocky headlands and peaks

Ridges and escarpments

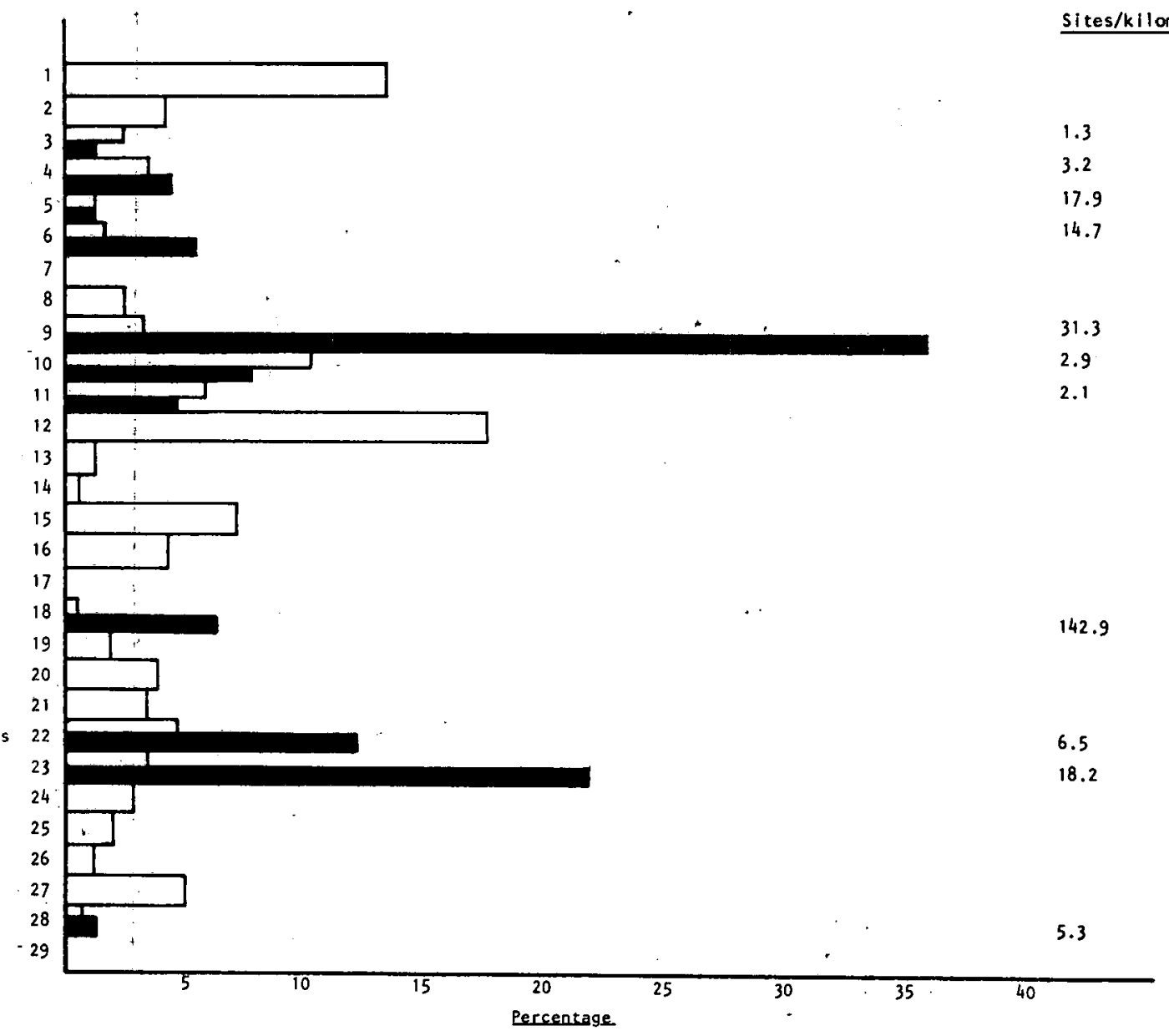

Figure 7. Percentage of sites and sites $/ \mathrm{km}^{2}$ compared to Land Management Units surveyed. 
THE RESURVEY

An archaeological resurvey was undertaken on a sub-sample of 10 quadrats selected from the first survey's sample (Figure 8). Further, selected sites within those quadrats were recorded. This step was undertaken in order to ascertain firstly, the accuracy and sufficiency of the original site identification, and, secondly, the accuracy of the site location pattern generated by the survey. These quadrats and sites were subjectively selected from each of the three physiographic divisions of the Island to include both coastal and inland quadrats containing sites.

The two issues were addressed through the employment of five methods which included small-scale excavation, structured surface collection, plans and transects (using a tachyometer), small bulk sample collection and the recording of changes in surface characteristics. Bulk samples were taken at regular intervals along selected transects to ascertain whether or not sites were more extensive than the surface evidence indicated. A rat-wall shovel was used to obtain these (Length $=40 \mathrm{~cm}$, width $-10 \mathrm{~cm}$, breadth $=10 \mathrm{~cm})$.

These methods were chosen, firstly, in order to illustrate that rapid survey and sampling techniques could, and in certain circumstances, should, be incorporated into site surveys undertaken to identify and describe the basic characteristics of the archaeological record. Secondly, they were employed to obtain additional data in the short period available (four weeks) for the development of an archaeological management plan for Moreton Island. This was particularly important in view of the imminent threat of sand mining.

The selected quadrats were resurveyed to locate sites recorded on the previous survey and to record any new sites found. Transects of selected site areas were undertaken to illustrate aspects of site location. Excavations, bulk samples and collections were undertaken on eroded or otherwise disturbed sites in order to illustrate that sites often rated archaeologically unimportant due to their "poor condition" or disturbed nature can be of significant value. The resurvey was commenced in May 1980, 12 months after the initial survey, and took 144 person-hours to complete.

It produced some interesting results including a few caveats. Most. significant was that substantial changes had occurred to sites. Of the sites originally recorded $15 \%$ had disappeared and the characteristics of a further $42 \%$ had been significantly altered. This was due either to physical changes to sites or as a result, of additional data obtained through the use of more detailed recording techniques.

As a result, modification to the original description of some sites had to be made. The sites on the southwest coast (62-93) can now be interpreted as forming part of a large site complex rather than as a series of discrete sites. Sites 44-49 may also be regarded as a single deposit rather than as separate sites. However, additional work, including a series of dates, is needed to further clarify the situation. Collection and excavation on sites 19,31-37, 58 and 59, confirmed their original description as sites comprising small piles of shell. In addition, four sites were found that were not previously recorded. Two of these, sites $19 \mathrm{~b}$ and One Tree, have been dated to $1157 \pm 50 \mathrm{~b} . \mathrm{p}$. and $1620 \pm 60 \mathrm{~b} \cdot \mathrm{p}$. respectively. These are the earliest dates yet obtained for archaeological sites on Moreton Island. Despite changes to Individual sites, the overall pattern of site location in the resurveyed quadrats remained the same as that generated by the original survey. Similarly, the general pattern of site distribution was not affected. 


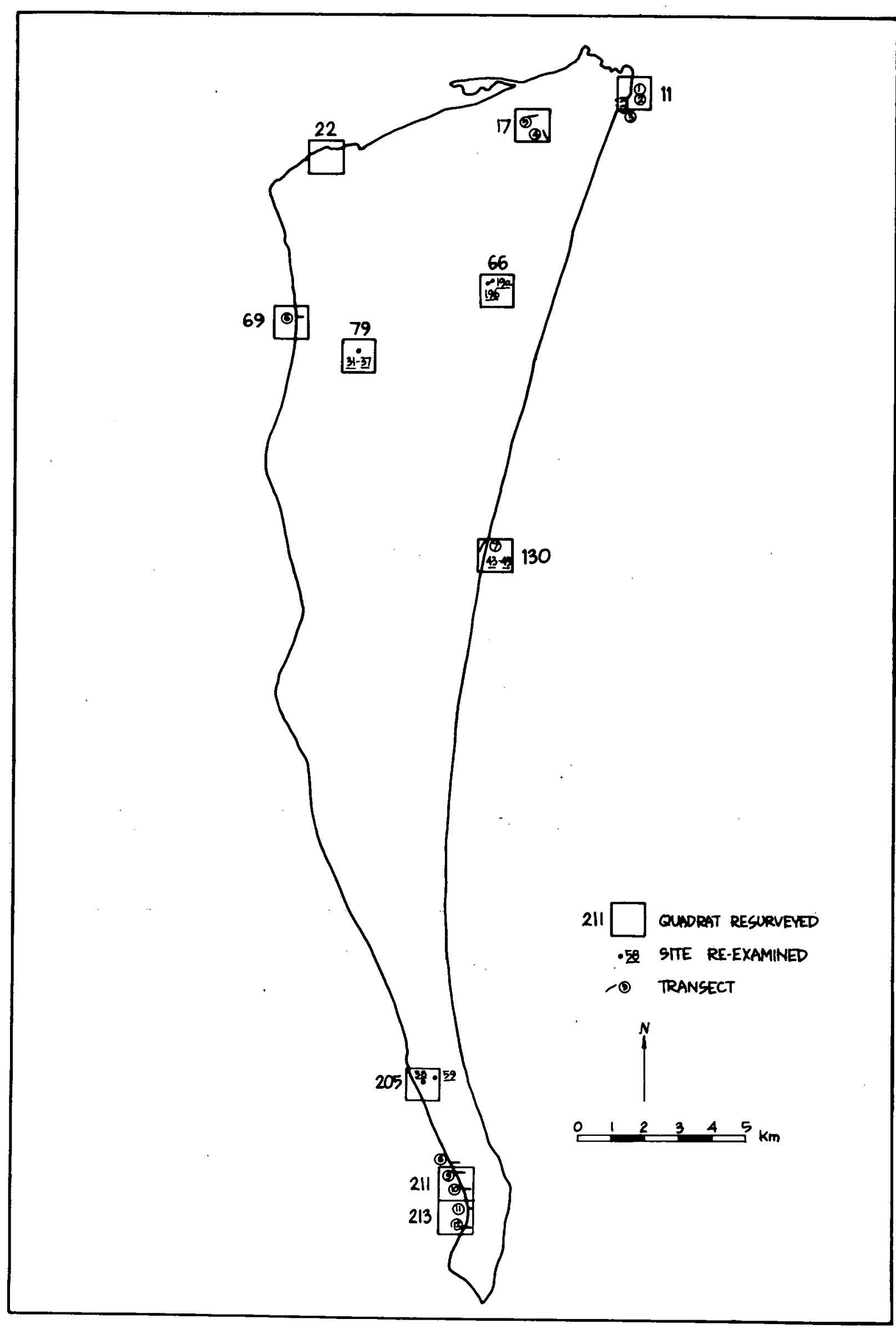

Figure 8. Quadrats, sites and transects selected for resurvey. 


\section{REFERENCES}

Byrne, J. 1912. Queensland Museum correspondence no. 12/609, 25.10 .1912 .

Coaldrake, J.E. and Turner, T.L. 1976(b) The Lands of Moreton Island. In, A.A. Heath and Partners Pty Litd, Moreton Island: Environmental Impact Study and Strategic Plan (A report prepared for the Co-Ordinator General's Department, Queensland) (2): 50-66.

Durrington, L.R. 1977 Vegetation of Moreton Island. Technical Bulletin no. 1. Botany Branch, Department of Primary Industries, Brisbane.

Ha1l, H.J. 1980 Archaeology at the University of Queensland. Australian Archaeology 10: 79-85.

Heath, A.A. and Partners Pty Ltd. 1976 Moreton Island: Environmental Impact Study and Strategic Plan (A report prepared for the Co-Ordinator General's Department, Queensland).

'Morwood, M.J. 1975 Moreton Island Archaeological Survey - Preliminary Report. Unpublished manuscript. Archaeology Branch, Department of Aboriginal and Islanders' Advancement, Queensland.

Ponosov, V.V. n.d. Results of an Archaeological Survey of the Southern Region of Moreton Bay and of Moreton Island (1963-1964). Department of Psychology, University of Queensland.

Quinne11, M.C. 1975 Aboriginal and Archaeological sites. In, P. Mather (ed.) The National Estate in Moreton and Wide Bay Burnett Regions, South East Queensland and Recommendations on its Managements pp. 171-207, Queensland Museum, Brisbane.

Redman, C.L. 1974 Archaeological Sampling Strategies. Addison-Wesley Module in Anthropology. no. 55. Philippines.

Richardson, N.A. 1979 The Sources of Raw Materials and their Use in the Manufacture of Prehistoric Stone Artefacts on Moreton Island. Unpublished BA(Hons) thesis, University of Queensland.

Robins, R.P. 1983 This Widow Land: an evaluation of public archaeology in Queensland using Moreton Island as a case study. Unpublished MA thesis, University of Queensland.

Zehna, P.W. 1974 Introductory Statistics. Prindle, Weber and Schmidt Inc., Boston. 